\title{
Management and Utilization Strategy of Water Resources for Rice Production
}

M B Hossain ${ }^{1}$, M Maniruzzaman'1, A K M S Islam², M U Salam³ and M S Kabir ${ }^{4}$

\begin{abstract}
Declination of available water resources is threatening the dry season crop production in Bangladesh. Sustainable water management is crucial need to meet future food production. This study was aimed to determine futuristic water management strategy for rice cultivation. Both surface and groundwater is getting scarce in north-west region, whereas abundant of fresh surface water creating opportunities to irrigate dry season crops in south-central region. This study has outlined irrigation management for rice cultivation and groundwater utilization in water scarce area of north-west region. More than $75 \%$ of annual rainfall occurred during monsoon and crops other than monsoon often faced water shortage. Timely establishment of T. Aus rice on 01 May accounted average $183 \mathrm{~mm}$ supplemental irrigation for north-west and south-west region. Transplanting of T. Aman rice before 24 July found the low risk period of drought and gave about $1 \mathrm{tha}^{-1}$ yield advantage than late transplanting after 15 October. Supplemental irrigation in drought year gave up to $26 \%$ yield advantage than the rain-fed condition of T. Aman rice in experimental plot. Over exploitation of groundwater by famers for crop cultivation makes the groundwater status worsen. Farmers used $38 \%$ excess water than the actual requirement for Boro rice cultivation. For that annual groundwater withdrawal was higher than annual recharge causing groundwater level depletion in most of the districts. Groundwater table went below suction limit of shallow tubewell (STW) during dry season and thus it become unable to operate. Improved distribution system with plastic pipe, buried pipe could save about $25 \%$ of irrigation water. Alternate wetting and drying (AWD) irrigation method saved 20-25\% water than farmer's practice. Application of these on-farm water management technologies in Boro rice reduced water demand and made the groundwater balance positive as well as reduced the groundwater withdrawal pressure. On the contrary, irrigation with less saline surface water resources in river and canals of south central regions could expand Boro production and increased land productivity. Intervention of low lift pump with plastic pipe distribution in non-saline tidal areas could increase land productivity. Besides, trapped freshwater in to the canals inside the polders and re-excavation of these canals would make crop intensification. Thus, additional food production could help to achieve sustainable development goal and sustained food security.
\end{abstract}

Key words: Supplemental irrigation, recharge, groundwater balance, less saline surface water, rice cultivation

\section{INTRODUCTION}

The sustainable use and management of freshwater resources are growing more concerns at present days for irrigated agriculture. Since water is one of the key inputs to agriculture, crop productivity largely depends on it. Bangladesh has achieved tremendous success in agriculture over the last three decades, especially in rice cultivation, and reached self-sufficiency in rice production (Mainuddin and Kirby, 2015; Timsina et al., 2018; Kabir et al., 2015). It is a densely populated country with intensive crop cultivation. About $79 \%$ of the total cultivated land in Bangladesh depends on groundwater irrigation and the remaining area is irrigated by surface water (Qureshi et al., 2014). The excess withdrawal of groundwater then recharged causing water table declination (BRRI, 2019). A 10 years (2007-2016) groundwater table analysis showed a declining trend in the Chapai Nawabganj district (Hasan et al., 2018). Consequently, the groundwater table goes below the suction limit of shallow tubewell (STW) in the Rajshahi area (BRRI, 2019). Mojid et al., 2019 stated a significant $(\mathrm{p} \leq 0.05)$ falling

\footnotetext{
${ }^{1}$ Irrigation and Water Management Division, Bangladesh Rice Research Institute (BRRI), Gazipur-1701, Bangladesh; ${ }^{2}$ Farm Machinery and Postharvest Technology Division, BRRI, Gazipur-1701, Bangladesh; ${ }^{3}$ Freelance International Consultant (Agricultural Systems), Bangladesh; ${ }^{4}$ Director General, BRRI, Gazipur-1701, Bangladesh.

*Corresponding author's E-mail: belal.iwm@gmail.com (M B Hossain)
} 
trend of the annual maximum depths of groundwater table (GWT) in $65.71 \%$ of the monitoring wells revealed a continuous increase in groundwater abstraction in the north-west region of Bangladesh. They also reported that a significant falling trend of the annual minimum depths of GWTs in $69.71 \%$ of the monitoring wells revealed groundwater mining. Within the north-west region, Rajshahi, Pabna, Bogura, Dinajpur, and Rangpur were identified as severely depleted areas, with depletion of GWTs between $2.3 \mathrm{~m}$ and $11.5 \mathrm{~m}$ (Dey et al., 2013). Irrigation dependency for intensive crop cultivation with modern highyielding varieties is one of the key factors of groundwater level depletion. Expansion of irrigated rice (Boro) cultivation causing the excess withdrawal of groundwater. Besides, excess use of water by farmers than its demand causes excess withdrawal. Hossain et al., 2016 reported that farmers used $20.2 \%$ excess water than required in Boro rice cultivation. They also revealed that a combination of alternate wetting and drying irrigation and a plastic pipe distribution system can save $40 \%$ irrigation than farmers management. Similar findings were also reported by Maniruzzaman et al., 2019. By applying AWD, farmers or pumpowners are able to save 15 to $30 \%$ of their irrigation water (Bouman et al., 2007).

On the contrary, a large area of the southcentral region remains fallow during the dry season and has a great opportunity to crop intensification. Ibrahim et al., (2017) reported that Fallow-Fallow-T. Aman is the most dominant cropping pattern in the region and occupied $13.0 \%$ of the net cultivable area. Besides, water salinity remains at the permissible limit of irrigation during the dry season in most of the areas of the Barishal region (BRRI, 2019). An extensive canal network exists inside the polder of the Barishal region occupied with fresh water. Bangladesh is a densely populated country with 168 million current population and has been projected to increase to 215.4 million in 2050 (Kabir et al., 2015). To meet the growing demand for food, an increase in productivity of both rainfed and irrigated agriculture, specifically Boro rice cultivation is required (Mainuddin and Kirby, 2015). To feed the increasing people, there is no other option to increase food production by adapting and mitigating adverse effects on Bangladesh agriculture under changing climatic situation. Sustainable water resources management is inevitable to cope with the challenges. Besides, horizontal expansion of dry season rice in the coastal region will contribute to the national food basket. In order to sustain food security, judicious application of water will play a key role. This article specially focused on north-west, south-west and southcentral hydrological region of Bangladesh with the following objectives to

- Identify suitable irrigation management practice for $T$. Aus and T. Aman rice cultivation;

- Develop a future action plan of safe groundwater irrigation;

- Determine the safe groundwater withdrawal in north-west hydrological region;

- Uutilize the surface water for dry season crop cultivation in the south-central region; and,

- Develop and map the action plan for three decades on reducing yield loss from water stress.

\section{METHODOLOGY}

\section{Data collection}

Historical (1987-2016) groundwater table data of the north-west hydrological region were collected from Bangladesh Water Development Board (BWDB). Thirty years of water level data of 100 observation wells were analyzed. Historical (36 years from 1981) weather data of rainfall, temperature, wind speed, humidity, and sunshine hours were collected for seven weather stations (Rangpur, Dinajpur, Ishwardi, Rajshahi, Bogura, 
Chuadanga, and Jashore) from Bangladesh Meteorological Department (BMD) to determine irrigation water requirement of major growing crops in the study regions. District wise area coverage of different crops was gathered from the Year Book of Agricultural Statistics (BBS, 2012 to 2018).

\section{Irrigation requirement vs irrigation applied to crops}

Hossain et al., 2017 estimated irrigation water requirement and irrigation scheduling of Boro and T. Aman rice in the north-west hydrological region of Bangladesh. The CROPWAT 8.0 model (Allen, et al., 1998) was used to estimate net irrigation requirements considering crop, soil, weather, and management practices. The amount of supplemental irrigation for $\mathrm{T}$. Aus and $\mathrm{T}$. Aman rice and net irrigation requirement of major crops in the study region was estimated using the model. Crop wise actual data on irrigation, applied by farmers in different regions were collected from Bangladesh Rice Research Institute (BRRI) and Bangladesh Agriculture Research Institute (BARI) studies.

\section{Estimation of annual groundwater recharge}

This study used the water table fluctuation method to estimated groundwater recharge (Healy and Cook, 2002). The recharge volume is given by;

$$
R=\Delta H \times S_{y}
$$

Where, $\mathrm{R}=$ recharge $(\mathrm{m}) ; \Delta \mathrm{H}=$ average groundwater level fluctuation $(\mathrm{m})$; and, $\mathrm{S}_{\mathrm{y}}=$ specific yield (dimension less).

Based on the laboratory test and field survey by the Institute of Water Modelling (IWM) in collaboration with BWDB, Water Resources and Planning Organization (WARPO), Barind Multipurpose Development Authority (BMDA), Department of Public Health Engineering (DPHE), they reported that the specific yield for the study area ranges between 0.08 to 0.09 . Besides this, a great portion of water could be recharged from irrigated rice fields as percolation. FAO CROPWAT 8.0 model was used to determine the percolation water from the rice field in this study. The volume of recharged water has been calculated by multiplying the average depth of recharged water to the area of the district. The volume of percolation water was the product of percolation depth to Boro area coverage.

\section{Groundwater balance study}

Groundwater storage was calculated from annually recharged and withdrawal of water. Groundwater was abstracted for irrigation by all the crops and domestic uses. About $62 \mathrm{~L}$ water person ${ }^{-1}$ day $^{-1}$ was considered in domestic use in the study region (Milton et al., 2006) However, this study did not consider industrial use of water since less industrial area and was negligible water use compared to irrigation. The declination of the minimum groundwater table indicated the negative balance of groundwater and vice versa. The reduced amount of groundwater withdrawal was calculated following the trial and error method to make groundwater balance positive. This study considered the reduction of water used from the rice field by utilizing water-saving technologies during Boro rice cultivation. Groundwater balance was studied in two approaches as existing farmers' water management in Boro rice and actual irrigation requirement. The amount of irrigation applied in non-rice crops remained the same in both the approaches.

\section{Determination of surface water salinity dynamics}

BRRI has conducted a consecutive three years study from 2016 to monitor the water salinity of major river systems in the Barishal region (BRRI, 2019). Water salinity of Tentulia, Buriswar, Bishkhali, and Boleswar was measured at fixed points during the dry season (December to May). Finally, a point of each river was selected where water salinity remains $<1 \mathrm{dS} \mathrm{m}^{-1}$. The surface water resources from 
the point to upstream were considered as suitable for irrigation. BRRI has assessed the amount of freshwater available for irrigation inside the polder 43/1 at Amtali, Barguna (Maniruzzaman et al., 2019). The volume of water stored in the canals was calculated by taking the length, width, and depth of canals. The possible area under crop cultivation was calculated from stored water and seasonal water requirement of dry season crops.

\section{RESULTS AND DISCUSSION}

\section{Yield loss scenarios from water stress}

Uneven distribution of rainfall during the monsoon often causes water shortage and $\mathrm{T}$. Aman rice faces terminal drought from this. Since the rice plant is sensitive to water stress in its reproductive phase, yield loss occurs in most areas of Bangladesh. Roy et al., 2010 estimated about $13 \%$ yield loss in the experimental plot due to water stress in the reproductive phase of BR11 in the T. Aman rice season in Kushtia district. Up to $21 \%$ yield reduction of BRRI dhan49 was reported in rainfed T. Aman rice in BRRI farm, Gazipur (BRRI, 2018). Besides, rainfall shortage during July to August often delayed the transplanting of $\mathrm{T}$. Aman rice resulting in increased seedling age and consequently facing yield loss. The same scenarios happen in T. Aus rice where farmers are unwilling to apply supplemental irrigation for timely crop establishment. BRRI study estimated about $25-30 \%$ yield loss due to water stress in the early period of T. Aus rice in the experimental plot. Timely pump operation by the pump owner is one of the major threats for transplanting recommended aged seedlings. Delay transplanting with aged seedling reduces the yield of Boro rice. Considering all the issues about $0.5 \%$ annualized yield loss has been estimated due to water stress (Kabir et al., 2020)

\section{Rainfall variability}

Rainfall distribution of north-west and southwest regions was analyzed (Fig. 1). The annual normal rainfall of the seven stations varied from 1467 to $2290 \mathrm{~mm}$. The highest $(2290 \mathrm{~mm})$ rainfall was observed in Rangpur followed by $1990 \mathrm{~mm}$ in Dinajpur and $1750 \mathrm{~mm}$ in Bogura. In all stations, more than $75 \%$ of rainfall occurred during the monsoon (June to October). Crops other than monsoon often face drought and irrigation needs to apply for obtaining the desired yield.

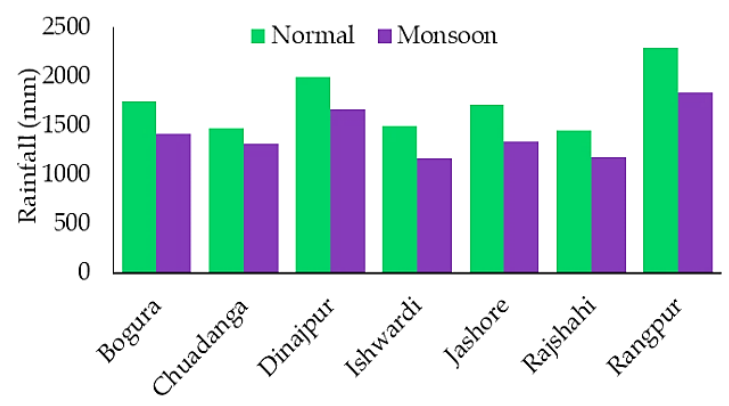

Fig. 1. Normal annual and monsoon rainfall (1981-2017) in key points of the study locations in Bangladesh.

\section{Water management for Aus rice production}

Average rainfall during May varied from 120 to $277 \mathrm{~mm}$ in the study locations (Fig. 2). However, 200-250 $\mathrm{mm}$ water is required in land preparation for $\mathrm{T}$. Aus rice cultivation. Thus, supplemental irrigation needed to apply for timely land preparation. Besides uneven distribution of rainfall often causes early drought of T. Aus rice in many regions.

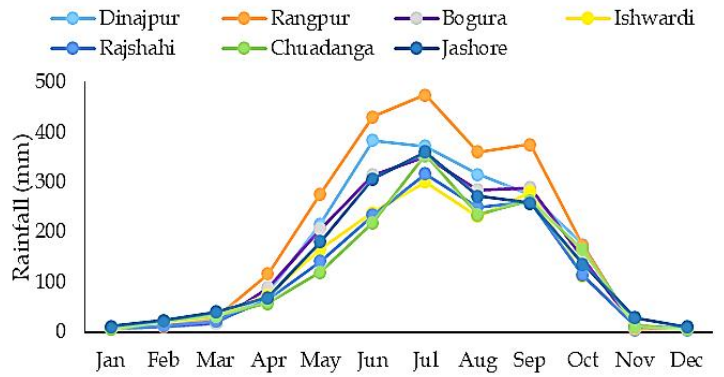

Fig. 2. Distribution of monthly normal rainfall in selected locations in Bangladesh.

CROPWAT model estimated an average of 183 $\mathrm{mm}$ (3 nos), $129 \mathrm{~mm}$ (2 nos), and $75 \mathrm{~mm}$ (1 no) supplemental irrigations for $\mathrm{T}$. Aus rice when it 
was transplanted on 1 May, 10 May, and 20 May respectively (Table 1). For 1 May transplanting, the highest $262 \mathrm{~mm}$ irrigation was accounted in Chuadanga whereas the lowest $60 \mathrm{~mm}$ in Rangpur. Similarly, for 10 May transplanting, $198 \mathrm{~mm}$ irrigation was estimated for Jashore and $60 \mathrm{~mm}$ in Dinajpur, Rangpur, and Bogura region. Supplemental irrigation was not required in Dinajpur, Rangpur, and Bogura region when it was transplanted on 20 May. However, the highest $132 \mathrm{~mm}$ irrigation was required in Ishwardi and Jashore region.

\section{Terminal drought mitigation for T. Aman rice cultivation}

Studies (BRRI, 2016) showed that T. Aman rice often faced terminal drought due to uneven distribution of rainfall in the north-west and south-west region of Bangladesh. BRRI (2016) showed that long-duration varieties faced more drought than short-duration varieties. They also reported that delay transplanting of both short duration and long duration varieties of $T$. Aman rice after 24 July experienced more drought and yield loss occurred. Timely establishment of T. Aman rice before 24 July has yield advantage of about $1 \mathrm{t} \mathrm{ha}^{-1}$ than late transplanting after 15 August in rainfed condition.

A consecutive five-years study from 2010 to 2015 in the Kushtia region concluded that before 17 July transplanting is the low-risk period, 17-31 July is the medium risk and after 31 July transplanting is the high-risk period of drought for T. Aman rice cultivation. Hossain et al., (2017) also reported that the 15 July transplanting of T. Aman rice in the northwest region required no supplemental irrigation, whereas $279 \mathrm{~mm}$ (3 nos.) irrigation was needed for delay transplanting at 15 August. Application of supplemental irrigation was found effective drought mitigation options for $\mathrm{T}$. Aman rice cultivation. About $26 \%$ yield advantage was obtained by applying supplemental irrigation than rainfed condition (BRRI, 2017).

\section{Present status of groundwater resources of north-west Bangladesh}

Intensive groundwater irrigation has been practicing in the northern part of Bangladesh. As a result groundwater table is affected due to over withdrawal of water than recharge volume. Figure 3 illustrates the upazila-wise maximum groundwater level of the north-west hydrological region during 2017. It shows that among the 108 upazilas of the north-west hydrological region, the maximum groundwater level exceeds the suction limit (practically $8 \mathrm{~m}$ ) in 44 upazilas. It means groundwater resources are getting scarce in 44 upazilas and other upazilas remain safe for STW (shallow tubewell) operation. Except Rangpur regions, the minimum groundwater level is increasing both in Pabna and Bogura region indicated that recharge amount decreased than withdrawal. In Rangpur, the historical minimum groundwater level remained almost the same means sufficient recharge happened except a few years (Fig. 4).

Table 1. Requirement of supplemental irrigation for T. Aus rice for different transplanting dates in the study locations of Bangladesh.

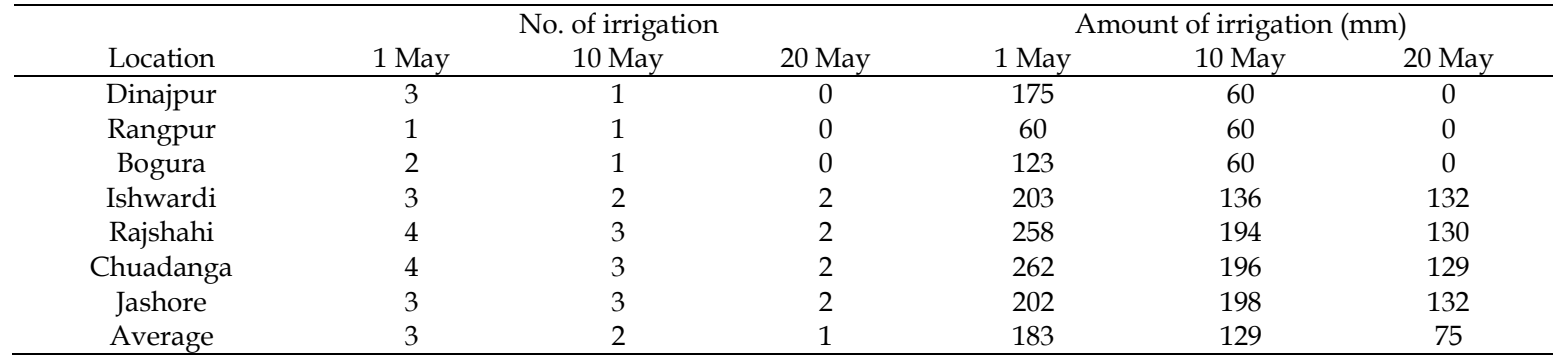




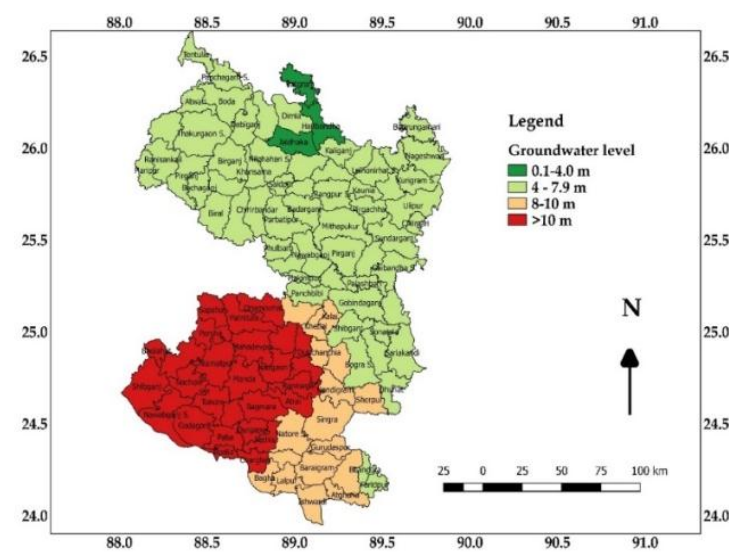

Fig. 3. Maximum groundwater level at north-west region of Bangladesh during 2017.
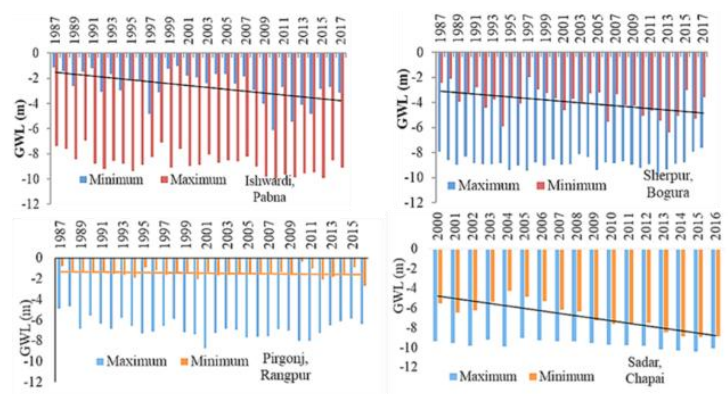

Fig. 4. Groundwater status at Pabna, Bogura, Rangpur and Chapai Nawabganj districts of Bangladesh during 1987 to 2017.

\section{Relationship between rainfall and recharge}

Generally, groundwater recharge occurs from rainfall, surface water storage bodies, river flow, irrigated rice field, etc. A close relationship was found betweenthe amount of annual rainfall and annual recharge (Fig. 5). Results showed that recharge depth is directly proportional to annual rainfall both in Pabna and Bogura districts. Figure 6 showes typical example in the Pabna district. It shows that annual rainfall at Pabna has decreased at $6 \mathrm{~mm}$ per year and recharge depth decreased at a rate of $2 \mathrm{~mm}$ per year. Although this relationship is statistically insignificant, it may be occurred due to uneven distribution and increased intensity of annual rainfall in the region.
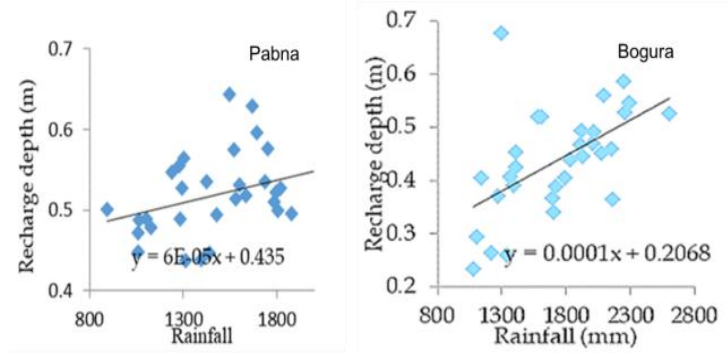

Fig. 5. Relationship between rainfall and groundwater recharge in Pabna and Bogura district of Bangladesh.

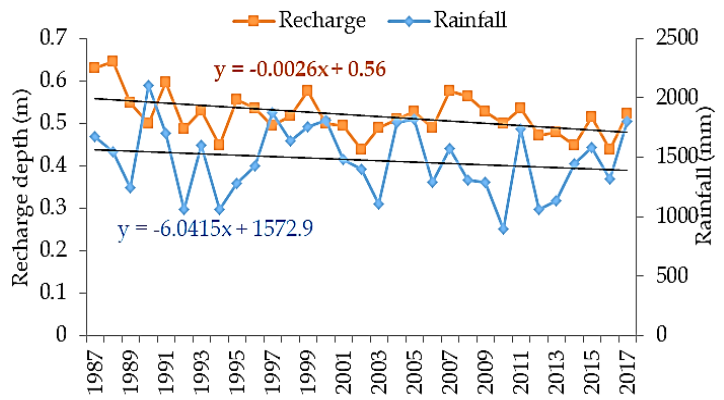

Fig. 6. Historical trend of rainfall and recharge depth at Pabna district of Bangladesh.

Irrigation requirement vs irrigation applied in major crops

Figure 7 shows the spatial distribution of irrigation water requirements of major crops. Boro rice required the maximum amount of irrigation since it is a waterloving crop and grown in fully irrigated conditions. The highest estimated irrigation requirement of Boro rice was $1056 \mathrm{~mm}$ at Bogura followed by $923 \mathrm{~mm}$ in Rajshahi and Dinajpur. The lowest irrigation requirement was $765 \mathrm{~mm}$ in Rangpur. Maize consumed the second-highest water next to Boro rice. The average $343 \mathrm{~mm}$ irrigation required for maize in the northwest hydrological region of which the highest 328 and the lowest $314 \mathrm{~mm}$ in Ishwardi and Rangpur, respectively. The average irrigation required for wheat, potato, mustard, and lentil was $194 \mathrm{~mm}$, $163 \mathrm{~mm}, 119 \mathrm{~mm}$, and $105 \mathrm{~mm}$, respectively. 


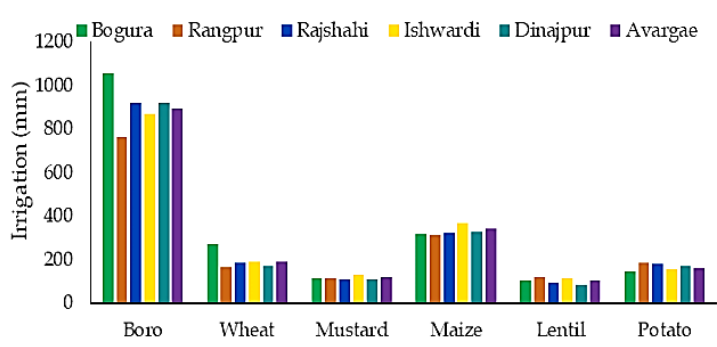

Fig. 7. Irrigation requirement of major crops in north-west region of Bangladesh.

Figure 8 shows detailed comparison of actual irrigation requirement and irrigation applied by farmers in the Boro season. Results show that farmers always use excess water than required. Farmers' practice applied an average of $38 \%$ more than the requirement in the north-west region of which the highest $50 \%$ water in Rangpur and the lowest $21 \%$ in Bogura. If farmers applied irrigation water for rice as per requirement, it would reduce the pumping cost as well as the groundwater withdrawal pressure.

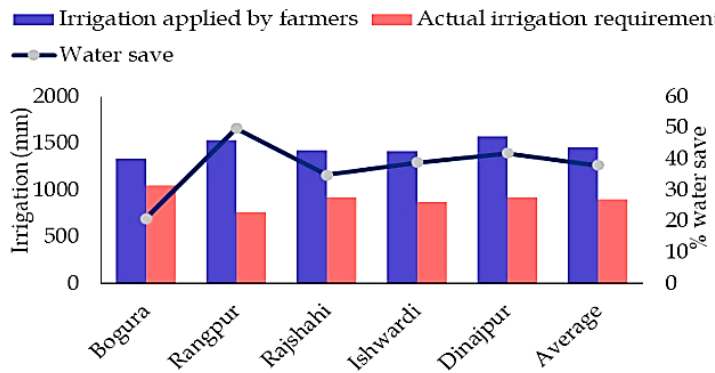

Fig. 8. Comparison of irrigation requirement and irrigation applied by farmers in different locations of northwest region of Bangladesh.

\section{Groundwater balance in north-west hydrological region}

Groundwater balance studies of Rangpur, Naogaon, Pabna, Bogura, and Joypurhat districts have been analyzed (Fig. 9). It shows that farmers are using excess water than recharged in each year from 2007 to onward. This excess withdrawal directly affected the groundwater table. But considering irrigation applied based on actual irrigation requirement the situation has been converted to positive groundwater balance. In Rangpur, on average,
0.2 billion cubic meters (BCM) per year groundwater shortage was faced since last 10 years due to over withdrawal following farmers practice. But an average of $0.55 \mathrm{BCM}$ per year excess groundwater was estimated following actual irrigation requirement approaches. The same scenarios were observed in all the locations except Joypurhat where both the approaches showed negative water balance due to less recharge. Thus, either surface water utilization should be popularized or the Boro area should be reduced in order to make groundwater sustainable in the region.

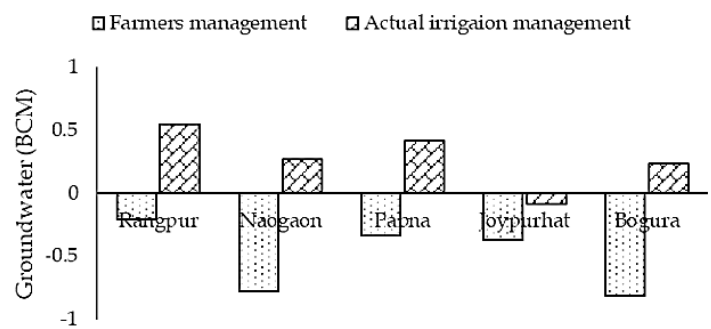

Fig. 9. Groundwater balance in farmer's management and actual irrigation requirement approaches in different districts of Bangladesh.

Since there is a good opportunity to retard groundwater table declination by less withdrawal of groundwater, the main emphasis should be given to optimizing groundwater irrigation. Irrigation to Boro rice based on its requirement should be the best option to make groundwater balance positive.

It is true that farmers are using excess water than the actual requirement all over the country. That is why proper utilization of water is a dire need especially in the waterscarce area of Bangladesh. Table 2 shows water balance for different management conditions in the study location. It was observed that at present $60 \%$ of the Boro area needed to bring under irrigation based on actual irrigation requirements in Bogura. In the Pabna district, it was $50 \%$ of the total Boro area, in Naogaon $70 \%$, in Joypurhat $100 \%$ and Rangpur $40 \%$ area under actual irrigation requirement is enough to make groundwater balance positive. 
Table 2. Groundwater balance (BCM) under different management condition in the selected study locations of Bangladesh.

\begin{tabular}{|c|c|c|c|c|c|c|c|c|c|}
\hline \multirow[t]{2}{*}{ Location } & \multirow{2}{*}{$\begin{array}{l}\text { Boro area } \\
\text { (ha) }\end{array}$} & \multirow{2}{*}{$\begin{array}{l}\text { Farmers' } \\
\text { manage- } \\
\text { ment }\end{array}$} & \multicolumn{7}{|c|}{ Boro area under actual irrigation requirement (\%) } \\
\hline & & & 20 & 30 & 40 & 50 & 60 & 70 & 100 \\
\hline Bogura & 185741 & -0.85 & -0.64 & -0.53 & -0.43 & -0.33 & -0.01 & 0.22 & 0.55 \\
\hline Pabna & 63346 & -0.33 & -0.19 & -0.12 & -0.04 & 0.04 & 0.11 & 0.26 & 0.41 \\
\hline Rangpur & 132796 & -0.20 & -0.11 & -0.03 & 0.04 & 0.12 & 0.19 & 0.34 & 0.49 \\
\hline Naogaon & 192009 & -0.771 & -0.61 & -0.50 & -0.38 & -0.29 & -0.18 & 0.08 & 0.24 \\
\hline Joypurhat & 68027 & -0.371 & -0.31 & -0.29 & -0.26 & -0.23 & -0.20 & -0.17 & -0.09 \\
\hline
\end{tabular}

Improvement of irrigation use efficiency by 2030 for sustaining Boro production

There is little scope for horizontal expansion of Boro rice cultivation in the northern part of Bangladesh. But the sustainability of Boro cultivation in the existing land is the key issue to future food security. Water security is a vital issue for rice production as well as other crop production in this region. But results showed that there is a good prospect to increase water use efficiency in the study region. Some issues need to be addressed to make Boro cultivation sustainable.

\section{Improved water distribution system}

The research finding shows that about $25 \%$ of irrigation water has been lost in the earthen canal distribution system and about $92 \%$ of that water can be saved using plastic pipe water distribution (Hossain et al., 2016). Government initiatives should be taken to reduce conveyance loss of water by buried pipe water distribution systems, PVC pipe distribution, and plastic pipe distribution. Bangladesh Agricultural Development Corporation (BADC), Barind Multipurpose Development Authority (BMDA), Department of Agricultural Extension (DAE),
Bangladesh Rice Research Institute (BRRI), and different NGO's should take action in this regard. Table 3 shows detailed outline of projected area coverage with improved water distribution.

\section{Improve field water use efficiency}

A huge scope exists all over the country to increase field water use efficiency. A definite irrigation scheduling based on actual irrigation requirements can improve water use efficiency. Alternate wetting and drying (AWD) irrigation method for irrigation is a technique to save irrigation of $20-25 \%$ water in this issue (Hossain et al, 2016). The mentioned study concluded that Intervention of AWD irrigation in $20 \%$ area of Bogura district can save 0.3 BCM water. In order to make Boro cultivation sustainable 1,11,444 ha, 3,16,73 ha, 5,31,18 ha, 9,60,08 ha and $6,80,27$ ha of Boro field should bring under AWD irrigation method in Bogura, Pabna, Rangpur, Naogaon, and Joypurhat district, respectively (Table 3). A detailed action plan has been proposed in Table 5 and Table 6 describing the area to be brought under AWD irrigation with other watersaving technologies.

Table 3. Proposed plan to bring Boro area under improved distribution and actual irrigation requirement.

\begin{tabular}{ccccc}
\hline Location & $\begin{array}{c}\text { Boro area } \\
\text { (ha) }\end{array}$ & \multicolumn{3}{c}{ Boro area under improved distribution and actual irrigation requirement } \\
& 2020 & 2025 & 2030 \\
\hline Bogura & 185741 & 18574 & 65009 & 111445 \\
Pabna & 63346 & 6334.6 & 19003.8 & 31673 \\
Rangpur & 132796 & 13279.6 & 33199 & 53118 \\
Naogaon & 192009 & 19200.9 & 57602.7 & 96004 \\
Joypurhat & 68027 & 6802.7 & 34013.5 & 68027 \\
\hline
\end{tabular}




\section{Surface water utilization}

Since groundwater resources become scarce, surface water use for irrigation should be one of the best options for sustaining agriculture. Pumping of river water for irrigation will reduce groundwater abstraction and increase recharge volume as percolation. The government should take initiative to expand $10 \%$ area of surface water irrigation by 2030 .

\section{Precision irrigation}

Precision irrigation like sensor-based irrigation and model-based irrigation scheduling should be adopted to maximize irrigation efficiency. Results showed that model-based irrigation can save up to $40 \%$ more water than conventional practices.

\section{Institutionalizing of irrigation to reduce overuse of water}

Privatization of irrigation facilities caused over-extraction of groundwater by farmers. As a result, the dissemination of water-saving technologies is found difficult all over the country. Institutionalization of water resources authority could be a good option to increase water use efficiency. The government will subsidize irrigation and provide it to farmers free of cost. But a defined authority will take a decision on when to irrigate the field and how much.

\section{Scope of Boro cultivation in south-central (Barishal) region}

Less crop diversity was found in the Barishal region due to some adverse conditions like salinity, tidal water, and water stagnation. But extensive river and canal networks are the key blessings in this region. The crop sector remains underdeveloped in the coastal region although a good scope exists there. Cropping intensity values were observed 107-249\% although 1,44,405 ha of land was a single cropped area (Ibrahim et al., 2017). Figure 10 shows the dry season fallow land in different districts of the Barishal region.

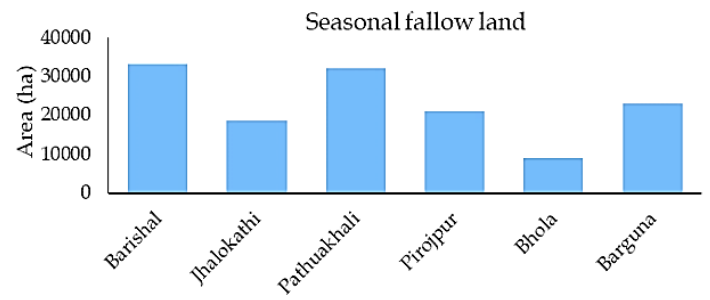

Fig. 10. Fallow land during dry season at Barishal region of Bangladesh.

Among the six districts, Barishal has the highest 33,320 ha of dry season fallow land followed by Patuakhali (32,020 ha), Barguna (23,000 ha), and Jhalokathi (18,660 ha). Cropping intensity was higher in the Bhola district and the seasonal fallow area was found 9,130 ha. Thus, the Barishal region has a good opportunity to improve cropping intensity by introducing Boro rice.

\section{Water salinity dynamics of surface water bodies}

Three consecutive years' study since 2016 on water salinity dynamics of the major river system has been summarized (Table 4). The result shows that Tentulia, Burishwar, and Bishkhali rivers are comparatively less saline than Boleswar. The maximum electrical conductivity in Tentulia river at Panpatti ghat, Golachipa was found as $0.760 \mathrm{dS} \mathrm{m}^{-1}$ (below 1 $\left.\mathrm{dS} \mathrm{m}^{-1}\right)$. This indicated that water from the upstream side from this point was suitable for irrigation during the dry season. Similarly, salinity remains $<1 \mathrm{dS} \mathrm{m}^{-1}$ round the year at Chotobogi point in Buriswar river (0.930 dS m$\left.{ }^{1}\right)$, Kakchira ferry ghat point of Biskhali river $\left(0.968 \mathrm{dS} \mathrm{m}^{-1}\right)$, and Charkhali ferryghat point of Boleswar river $\left(1.080 \mathrm{dS} \mathrm{m}^{-1}\right)$. As a result, river and canal water above these points remained safe for irrigation. Boro cultivation in the areas below this point is also possible by introducing salt-tolerant cultivars. Diversion of freshwater from upstream to downstream part should be another option to irrigate Boro field. 
Table 4. Water salinity at transition point of major rivers in Barishal region of Bangladesh.

\begin{tabular}{llccc}
\hline \multicolumn{1}{c}{ Location } & River & \multicolumn{3}{c}{ Maximum water salinity $\left(\mathrm{dS} \mathrm{m}^{-1}\right)$} \\
& & 2016 & 2017 & 2018 \\
\hline Charkahli ferry ghat, Bhandaria, Pirojpur & Boleswar & 0.981 & 0.910 & 1.080 \\
Kakchira ferry ghat, Bargunasadar, Barguna & Bishkhali & 0.968 & 0.560 & 0.550 \\
Chotobogi, Taltali, Barguna & Buriswar & 0.930 & 0.840 & 0.480 \\
Panpatti, Golachipa, & Tentulia & - & 0.550 & 0.760 \\
Patuakhali & & & & \\
\hline
\end{tabular}

Source: BRRI, 2019.

Water resources assessment and crop planning in polder area

The entire coastal region of Bangladesh is enclosed with 139 polders which control the movement of water inside the polder areas. A large extensive canal network exists in each polder is a good source of irrigation during the dry period. A study on water resources assessment in polder $43 / 1$ at Amtali, Barguna showed that among the 151 $\mathrm{km}$ long primary, secondary and tertiary canals (>10 m width), only $11 \mathrm{~km}$ canals are affected by different degrees of salinity. The total stored volume of water inside the canal was 7.414503 Million $\mathrm{m}^{3}$ in April with which about 650 ha of Boro field can be irrigated by trapping this water. Poor operation and maintenance of sluice gates, trapped canal for fish cultivation by a local leader, lack of distribution channels are the constraints to irrigation of Boro crops.

\section{Technological intervention for Boro expansion in coastal areas}

With sufficient water resources, a good opportunity exists in the Barishal region for crop intensification by introducing Boro rice during the dry season. Seventy percent area expansion in south-central (Barishal region) and $30 \%$ area in south-west saline region (Khulna) for Boro rice in fallow land by 2050 will lead to 0.75 MT additional rice in national production. Some technological interventions are needed to achieve the target in these areas. Table 5 and Table 6 showed the road map to technological intervention by 2050 for Boro rice expansion in the target locations.

\section{Intervention of low lift pump and plastic pipe distribution system}

BRRI study showed that Boro cultivation is feasible by irrigating the field from nearly canal water. Only a small intervention of low lift pump (LLP) with plastic pipe distribution system was found useful for Boro cultivation in these regions.

Burried pipe water distribution system to mitigate conveyance loss

Burried pipe water distribution system should be disseminated to convey irrigation water from the source (river, canal water) to the field. It will reduce the conveyance loss as well cost of production.

Proper operation of gate valves in the polder areas

Improper operation of gate valves is the main constraint to salinity intrusion in the polder area of Amtali, Barguna. Broken gate valves, poor gate operation, controlled by the local leader are the main issue.

\section{Re-excavation of secondary and tertiary canals}

Many secondary and tertiary canals were found to die due to siltation. These canals should be re-excavated. Besides new canals should be excavated to convey water to the tail end farmers. 
Table 5. Research plan for demonstration and adoption of water management technologies.

\begin{tabular}{|c|c|c|}
\hline Phase & & Activity \\
\hline \multirow{13}{*}{$\begin{array}{l}\text { Study and } \\
\text { research phase }\end{array}$} & & North-west and south-west (non-saline) region \\
\hline & 1. & Site selection and characterization through baseline survey, FGDs, SWOT analysis, etc. \\
\hline & 2. & $\begin{array}{l}\text { Stakeholder engagement for adoption and demonstration trials of water-saving } \\
\text { technologies } \\
\text { a. Water resource availability assessment, feasibility study of free water service/water } \\
\text { pricing on volume basis } \\
\text { b. Timely operation of the pump, installation of new DTW/STW for community basis, } \\
\text { operator selection } \\
\text { c. Construction of improved distribution system }\end{array}$ \\
\hline & & $\begin{array}{l}\text { Validation and adoption trials of water-saving technologies (AWD, distribution system, less } \\
\text { irrigation required cropping pattern, surface water storage and utilization) in farmers field } \\
\text { a. Problem identification, prioritization and scope identification for improvement } \\
\text { b. DTW/STW selection with progressive farmers, } \\
\text { c. Set trial at farmers' fields }\end{array}$ \\
\hline & & South-central and south-west (salt affected) region \\
\hline & 4. & Site selection and characterization through baseline survey, FGDs, SWOT analysis, etc. \\
\hline & & $\begin{array}{l}\text { Water resource assessment and stakeholder engagement for surface water irrigation } \\
\text { a. Suitable water body identification, proper operation of gate valves in the polder, } \\
\text { community engagement } \\
\text { b. Identification and excavation of poor and dead/bad canals to improve water storage }\end{array}$ \\
\hline & & $\begin{array}{l}\text { Demonstration and adoption of water management technologies in farmers field to increase } \\
\text { Boro production } \\
\text { a. Installation of LLP, portable solar pump and distribution system, } \\
\text { b. Progressive farmer selection and Block demonstration } \\
\text { c. c. Set trial at farmers' fields }\end{array}$ \\
\hline & & All regions \\
\hline & 7. & Training for farmers and other stakeholders \\
\hline & 8. & $\begin{array}{l}\text { Farmers' awareness building about water-saving technologies through print and electronic } \\
\text { media. }\end{array}$ \\
\hline & 9. & Wide-scale demonstration in the locality and organization of field days \\
\hline & 10. & $\begin{array}{l}\text { Economic viability analysis and farmers' feedback } \\
\text { a. Economic viability and feasibility analysis of the intervened water management } \\
\text { technologies } \\
\text { b. Farmers feedback }\end{array}$ \\
\hline \multirow[t]{2}{*}{$\begin{array}{l}\text { Scaling up } \\
\text { phase }\end{array}$} & 11. & $\begin{array}{l}\text { Extension linkage } \\
\text { a. Workshop, field visit etc. with concerned stakeholder }\end{array}$ \\
\hline & 12 & $\begin{array}{l}\text { Upscaling } \\
\text { a. Training for trainers } \\
\text { b. b. Print material for sharing of information and experience }\end{array}$ \\
\hline
\end{tabular}


Table 6. Target for enhancing rice production through introducing water management technologies and unexplored areas across future conditions.

\begin{tabular}{|c|c|c|c|c|c|c|}
\hline \multirow{2}{*}{$\begin{array}{l}\text { Cropping } \\
\text { Ecosystem }\end{array}$} & \multirow{2}{*}{$\begin{array}{l}\text { Area } \\
\text { coverage } \\
\text { (ha) }\end{array}$} & \multirow{2}{*}{$\begin{array}{l}\text { Target } \\
\text { intervention }\end{array}$} & \multirow{2}{*}{$\begin{array}{l}\text { Expected } \\
\text { production } \\
\text { increased (MT) }\end{array}$} & \multicolumn{3}{|c|}{ Time frame } \\
\hline & & & & $\begin{array}{l}2021- \\
2030\end{array}$ & $\begin{array}{l}2031- \\
2040\end{array}$ & $\begin{array}{l}2041- \\
2050\end{array}$ \\
\hline \multicolumn{7}{|l|}{ North-west and south-west (non-saline) } \\
\hline $\begin{array}{l}\text { Targeted area coverage under recommended } \\
\text { water management in T. Aus season }\end{array}$ & 365000 & 255000 ha & 0.008 & $30 \%$ & $40 \%$ & $30 \%$ \\
\hline WST1: Supplemental irrigation for T. Aus rice & - & 255000 ha & - & $30 \%$ & $40 \%$ & $30 \%$ \\
\hline $\begin{array}{l}\text { WST2: Los cost/free irrigation service to the } \\
\text { farmers }\end{array}$ & - & 255000 ha & - & $30 \%$ & $40 \%$ & $30 \%$ \\
\hline $\begin{array}{l}\text { WST3: Timely operation of tubewells for } \\
\text { irrigation during T. Aus season }\end{array}$ & - & 51000 nos. & - & $30 \%$ & $40 \%$ & $30 \%$ \\
\hline $\begin{array}{l}\text { Targeted area coverage underwater } \\
\text { management in T. Aman season }\end{array}$ & 2540884 & 1500000 ha & 0.30 & $30 \%$ & $30 \%$ & $40 \%$ \\
\hline $\begin{array}{l}\text { WST1: Supplemental irrigation in T. Aman } \\
\text { rice for timely establishment and mitigating } \\
\text { terminal drought }\end{array}$ & - & 1500000 ha & - & $30 \%$ & $30 \%$ & $40 \%$ \\
\hline $\begin{array}{l}\text { WST3: Timely operation of tubewells for } \\
\text { irrigation during T. Aus season }\end{array}$ & - & 150000 nos. & - & $30 \%$ & $30 \%$ & $40 \%$ \\
\hline $\begin{array}{l}\text { Water saving technology dissemination } \\
\text { during Boro rice cultivation }\end{array}$ & 2250000 & 1074570 & 0.1 & $30 \%$ & $30 \%$ & $40 \%$ \\
\hline $\begin{array}{l}\text { WST1: Alternate wetting and drying } \\
\text { irrigation method }\end{array}$ & - & 1074570 ha & - & $30 \%$ & $30 \%$ & $40 \%$ \\
\hline WST2: Improved distribution system & - & $86000 \mathrm{~km}$ & - & $30 \%$ & $40 \%$ & $30 \%$ \\
\hline WST3: Timely operation of irrigation wells & - & 215000 nos. & - & $30 \%$ & $40 \%$ & $30 \%$ \\
\hline \multicolumn{7}{|l|}{ South-central and South-west (saline) region } \\
\hline Targeted area coverage for Boro & 140636 & 140636 & 0.75 & $30 \%$ & $40 \%$ & $30 \%$ \\
\hline $\begin{array}{l}\text { WST1: Installation of low lift pump and/or } \\
\text { solar irrigation system }\end{array}$ & - & 32000 nos. & - & $30 \%$ & $40 \%$ & $30 \%$ \\
\hline $\begin{array}{l}\text { WST1: Improved distribution system by } \\
\text { plastic pipe/PVC pipe/buried pipe }\end{array}$ & - & $13000 \mathrm{~km}$ & - & $30 \%$ & $40 \%$ & $30 \%$ \\
\hline $\begin{array}{l}\text { WST1: Re-excavation of existing poor and bad } \\
\text { canals inside the polder } \\
\text { WST2: Excavation of new canals to stored }\end{array}$ & - & $20000 \mathrm{~km}$ & - & $50 \%$ & $25 \%$ & $25 \%$ \\
\hline $\begin{array}{l}\text { Block demonstration with modern varieties } \\
\text { by BRRI }\end{array}$ & 14063 & 3200 nos. & - & $30 \%$ & $40 \%$ & $30 \%$ \\
\hline Training and field days & & 3000 nos. & - & $30 \%$ & $40 \%$ & $30 \%$ \\
\hline Targeted area coverage for Aus & 416153 & 416153 & 1.20 & - & - & - \\
\hline $\begin{array}{l}\text { Block demonstration with modern varieties } \\
\text { by BRRI }\end{array}$ & 41615 & 4100 nos. & - & $30 \%$ & $40 \%$ & $30 \%$ \\
\hline Training and field days & - & 4000 nos. & - & $30 \%$ & $40 \%$ & $30 \%$ \\
\hline
\end{tabular}

\section{RECOMMENDATIONS}

- All pumps operated by government organizations, and privately should be opened timely during us, Aman and Boro season to ensure irrigation.
- Apply supplemental irrigation in T. Aus and T. Aman rice for timely establishment and to mitigate terminal drought in low rainfall areas. 
- Irrigation water pricing should be on volumetric basis.

- Distribution system should be improved by BADC, BMDA, DAE and relevant organizations.

- Massive demonstration of AWD irrigation methods should be done to popularize it.

- Institutionalization of irrigation sector is required to reduce overuse of water and provide irrigation free to farmers.

- Re-excavation of surface water bodies is needed to reserve more water to increase groundwater recharge.

- Massive block demonstration of Boro rice has to be done by using tidal water resources with the intervention of LLP.

- Freshwater harvesting is required in the canals inside the polder areas.

- Proper operation of gate valves of the polder has to be ensured.

\section{CONCLUSION}

The timely establishment of T. Aus rice needed supplemental irrigation in most of the regions. T. Aman rice transplanted before 24 July found the low-risk period of drought and gave significant yield advantage over late transplanting. Supplemental irrigation in $\mathrm{T}$. Aman showed upto $26 \%$ yield increase over the rainfed condition. Maximum groundwater level exceeded the suction limit of STW in 44 upazilas out of 108 in the north-west hydrological region of Bangladesh indicated DTW should be used for groundwater irrigation. Except the Rangpur regions, the minimum groundwater level is increasing both in Pabna and Bogura region pointed out that annual withdrawal surpassed the annual recharge. This resulted from decreased annual rainfall and overused water for irrigation. Farmers applied about 38\% more water than the actual irrigation requirement in the study region. The application of on-farm water management technologies can reduce excessive water withdrawal and make groundwater balance positive. Besides, huge freshwater resources in rivers and in extensive canal network inside the polder area have created opportunities to dry season crop cultivation in 144405 ha of fallow land in the Barishal region. Boro rice can be cultivated using freshwater resources in Tentulia, Bishkhali, Burishwar, and Boleswar rivers with the intervention of a low lift pump and improved distribution system.

\section{ACKNOWLEDGEMENTS}

The authors wish to thank anonymous reviewers for their suggestions, which significantly improved this article.

\section{AUTHORS' CONTRIBUTION}

$\mathrm{MBH}$ and $\mathrm{MM}$ generated idea; AKMSI coordinated the research; $\mathrm{MBH}$ and $\mathrm{MM}$ developed methodology; MBH, MM, MUS and MSK provided scientific insights; $\mathrm{MBH}$ gathered data, carried out analysis and synthesis; $\mathrm{MBH}$ and $\mathrm{MM}$ did the writings for versions of the manuscript; MUS, AKMSI and MSK performed critical review and editing; All authors read and approved the final manuscript.

\section{DECLARATION OF INTERESTS}

A version of the paper was published in a book "Doubling Rice Productivity in Bangladesh" in 2020 by the Bangladesh Rice Research Institute (BRRI), Gazipur 1701, Bangladesh to commemorate BRRI's 50th anniversary. The Bangladesh Rice Journal has prior knowledge of the book publication and does not see any conflict of interest.

\section{REFERENCES}

Allen, R, L A Pereira, D Raes and Smith M. 1998. Crop evapotranspiration. In: FAO Irrigation and Drainage Paper No. 56; FAO: Rome, Italy.

BRRI (Bangladesh Rice Research Institute). 2016. Terminal drought mitigation adopting transplanting dates in $\mathrm{T}$. 
Aman rice. BRRI Annual report 2014-15, Bangladesh Rice Research Institute, Gazipur-1701, Bangladesh, 86-87.

BRRI (Bangladesh Rice Research Institute). 2017. Effect of drought on different T. Aman varieties.BRRI Annual report 2016-17, Bangladesh Rice Research Institute, Gazipur-1701, Bangladesh, 101-102.

BRRI (Bangladesh Rice Research Institute). 2018. Effect of perched water table depletion on growth and yield of BRRI dhan49.BRRI Annual report 2017-18, Bangladesh Rice Research Institute, Gazipur-1701, Bangladesh, 93-94.

BRRI (Bangladesh Rice Research Institute). 2019. Assessment of groundwater level depletion dynamics in selected locations of Bangladesh.BRRI Annual report 2018-19, Bangladesh Rice Research Institute, Gazipur-1701, Bangladesh,101-106.

Bouman, B A M, R M Lampayan and T P Toung. 2007. Water management in irrigated rice: coping with water scarcity. Los Banos (Philipines): International Rice Research Institute, pp 21.

Chaturvedi, R S. 1973. A note on the investigation of ground water resources in western districts of Uttar Pradesh. In: Annual Report. U.P. Irrigation Research Institute, pp 86-122.

Dey, N C, S K Bala, A K M S Islam, M A Rashid and M Hossain. 2013. Sustainability of Groundwater Use for Irrigation in North-west Bangladesh. National Food Policy Capacity Strengthening Programme (NFPCSP): Dhaka, Bangladesh.

Hasan, M R, M G Mostafa, N Rahman, M S Islam and M M Islam. 2018. Groundwater depletion and its sustainable management in Barind tract of Bangladesh. Res. Journal of Environmental. Science, 12: 247-255.

Healy, R W and P G Cook. 2002. Using groundwater levels to estimate recharge. Hydrogeo-logy Journal, 10, 91-109.

Hossain, M B, D Roy, PLC Paul and M T Islam. 2016. Water productivity improvement using water saving technologies in Boro rice cultivation. Bangladesh Rice Journal, 20 (1) : 17-22.

Hossain, M B, S Yesmin, M Maniruzzaman and J C Biswas. 2017. Irrigation scheduling of rice (Oryza sativa L.) using CROPWAT model in the western region of Bangladesh. The Agriculturists, 15 (1): 19-27.

Ibrahim, M, M A U Zaman, A B M Mostafizur and S M Shahidullah. 2017. Diversity of crops and land use pattern in Barishal region. Bangladesh Rice Journal, 21 (2): 57-72.

IWM (Institute of Water Modeling). 2008. Determination of hydrogeological parameter of different regions of Bangladesh (North-west Region: Phase-1).
Kabir, M S, M U Salam, A K M S Islam, M A R Sarkar, M A A Mamun, M C Rahman, B Nessa, M J Kabir, H B Shozib, M B Hossain, A Chowdhury, M Nasim, K M Iftekharuddaula, M S Hossain, M K A Bhuiyan, B Karmakar, MS Rahman, M M Haque, M T Khatun, M P Ali, S M H A Rabbi, P L Biswas, E S M H Rashid and N M F Rahman. 2020. Doubling rice productivity in Bangladesh: A way to achieving SDG2 and moving forward. Bangladesh Rice Journal, 24 (2): 1-47.

Kabir, M S, M U Salam, A Chowdhury, N M F Rahman, K M Iftekharuddaula, M S Rahman, M H Rashid, S S Dipti, A Islam, M A Latif, A K M S Islam, M M Hossain, B Nessa, T H Ansari, M A Ali and J K Biswas. 2015. Rice Vision for Bangladesh: 2050 and Beyond. Bangladesh Rice Journal, 19 (2): 1-18.

Mainuddin, M and M Kirby. 2015. National food security of Bangladesh to 2050. Food Security, 7: 633-646.DOI: 10.1007/s12571-015-0465-6.

Maniruzzaman, M, M M Alam, M Mainuddin, M T Islam, M J Kabir, M Scobie and E Schmidt. 2019. Technological interventions for improving water use efficiency in the north-west region of Bangladesh. BRRI, Gazipur, Bangladesh.

Maniruzzaman, M, M J Kabir, M B Hossain, MS Yesmin, A B M Monstafizur, P K Kundu and M A Ali. 2019. Annual Report of Cropping system intensification in the salt-affected coastal zones of Bangladesh and West Bengal, India. BRRI, Gazipur-1701. 71p.

Milton, A H, H Rahman, W Smith, R Shrestha and K Dear. 2006. Water consumption patterns in rural Bangladesh: are we underestimating total arsenic load? Journal of water and health, 4(4):431-436.

Mojid, M A, M F Parvez, M Mainuddin and G Hodgson. 2019. Water table trend-a sustainability status of groundwater development in north-west Bangladesh. Water, 11:1182.DOI:10.3390/w11061182.

Qureshi, A S, Z Ahmed and T J Krupnik. 2014. Groundwater management in Bangladesh: An analysis of problems and opportunities. Cereal systems initiative for south asia mechanization and irrigation (CSISA-MI) project, Research Report No. 2., Dhaka, Bangladesh: CIMMYT.

Roy, D, M T Islam and B C Nath. 2010. Impact of supplemental irrigation applied at different growth stages of transplanted Aman rice (Oryza sativa L.). The Agriculturists, 8 (1):109-114.

Timsina, J, J Wolf, N Guilpart, L G J Van Bussel, P Grassini,V Wart, J Hossain, A Rashid, H Islam and S M K Van Ittersum. 2018. Can Bangladesh produce enough cereals to meet future demand? Agricultural System, 163: 36-44. 